\title{
Difference in somatic embryogenetic ability of cultured leaf explants of four genotypes of Solanum melongena $\mathrm{L}$
}

\author{
PV Lakshmana Rao * \\ Defense Research Laboratory, Post Bag No 2, Tezpur 784001 Assam, India
}

(Received 15 October 1991; accepted 1 April 1992)

\begin{abstract}
Summary - High frequency of somatic embryogenesis was obtained from leaf explants of 4 genotypes of Solanum melongena $L$. Varietal response was noticed with reference to optimum concentration of NAA required for somatic embryogenesis. Percent explants forming somatic embryos varied from 15.2-90.3, mean number of plants regenerated/explant from 1.5-29.5. In terms of their embryogenic competence and plant regeneration the genotypes could be rated in decreasing order as $F_{1}$ hybrid Suphal followed by PPL, DRLS and Kalalong. Initital inoculum size had a distinct correlation with number of plants regenerated. Decline in embryogenic competence was observed in all 4 genotypes under long-term culture. Plantlets regenerated from somatic embryos were established on soil and grown to maturity.
\end{abstract}

Solanum melongena = egg plant / leaf explant / somatic embryogenesis / genotypic response

Résumé - Embryogenèse somatique d'explants de feuilles de quatre génotypes de Solanum melongena. Des explants foliaires de 4 génotypes de Solanum melongena $L$ donnèrent lieu, avec une fréquence importante, à de l'embryogenèse somatique. Les réponses variétales furent notées, en corrélation avec la concentration d'acide $\alpha$ naphtylacétique (ANA) nécessaire pour l'embryogenèse somatique. La proportion d'embryons somatiques formés varia de 15,2 à 90,3 pour 100 embryons et le nombre moyen de plantes régénérées par embryon de 1,5 à 29,5. On peut classer les génotypes en fonction de leur compétence pour l'embryogenèse et la régénération de plantes de la façon suivante : hybride $F_{1}$ Sulphal, PPL, DRLS, Kalalong, par ordre décroissant. Le nombre de plantes régénérées était en rapport direct avec la taille initiale de l'inoculum. Un déclin de la compétence à l'embryogenèse fut observé par les 4 génotypes sur les cultures âgées. Les plantules régénérées à partir d'embryons somatiques furent cultivées sur sol, jusqu'à maturité.

Solanum melongena = aubergine / explant foliaire / embryogenèse somatique / réponse génotypique

\section{INTRODUCTION}

Regeneration of plantlets from cultured cells is an essential part of plant biotechnology. Somatic embryogenesis is one of the preferred pathways of induced plant regeneration. It can be either indirect from callus, cell suspension, or protoplast culture or direct from organ tissues such as leaf, stem, hypocotyl etc (Williams and Maheswaran, 1986). Successful induction and realization of somatic embryogenesis in a number of species have opened the possibility of us- ing somatic embryos as a potential propagation system for seed sown crops (Stuart et al, 1987).

Plantlet regeneration in $S$ melongena $L$ through organogenesis and embryogenesis is possible from sexual embryos (Yamada et al, 1967) hypocotyl (Kamat and Rao, 1978; Matsuoka and Hinata, 1979) leaf explants (Gleddie et al, 1983; Rao and Singh, 1991). The present study reports the difference in somatic embryogenesis ability of 4 varieties of $S$ melongena $L$ viz DRLS (DRL Selection), Kalalong, $F_{1}$ hybrid Suphal and PPL (Pusa Purple Long). The effect

\footnotetext{
- Correspondence and reprints; present address: Toxicology and Pharmacology Division, Defence Research and Development Establishment, Gwalior, 474002, India
} 
of inoculum size on plant regeneration and the embryogenic competence in long term culture were also studied.

\section{MATERIAL AND METHODS}

\section{Plant material}

Seeds of different genotypes tested in the present study and their sources were as follows: DRLS (Defence Research Laboratory, Tezpur) PPL (National Seeds Corporation, New Delhi), $F_{1}$ hybrid Suphal (Indo-American Hybrid Seeds, Bangalore), Kalalong (locally purchased). These 4 origins were selected because of their high yields and suitability for cultivation in mid and high altitude regions of north-eastern India.

Seedlings were established from seeds in the nursery during the months of December - February. Leaf explants were taken from 20-25 d-old seedlings. Preparation of explants and other culture conditions were the same as described earlier (Rao and Singh, 1991). Briefly, mature dark green leaves from 3-4 week old seedlings were surface sterilized in $0.1 \%(\mathrm{w} /$ v) mercuric chloride for 2 min followed by a 30-s rinse in $70 \%$ alcohol and repeated washings in sterilized distilled water. The leaves were transversely dissected into 3 pieces and the apical ends discarded. The middle portion was again transversely cut into 3-5 $\mathrm{mm}$ sections and placed abaxial side down on the medium.

\section{Culture medium}

The basal medium used in the present study was that of Murashige and Skoog (1962) supplemented with $3 \%(\mathrm{w} / \mathrm{v})$ sucrose, $100 \mathrm{mg} / \mathrm{l}$ myo-inositol, and $0.8 \%(\mathrm{w} /$ v) agar and hereafter referred to as MS basal medium. NAA was incorporated at $0.5-12.0 \mathrm{mg} / \mathrm{l}$ in 7 concentrations $(0.5,1.0,2.0,4.0,8.0,10.0$ and $12.0 \mathrm{mg} / \mathrm{l})$ in combination with $0.1 \mathrm{mg} / \mathrm{kinetin}$ as it was found beneficial in promoting somatic embryogenesis (Rao and Singh, 1991). The $\mathrm{pH}$ of the medium was adjusted to 5.6-5.8 before autoclaving. For callus initiation, the explants were cultured on $15 \mathrm{ml}$ of medium in $25 \mathrm{x}$ $150-\mathrm{mm}$ tubes. Suspension cultures were raised in $250-\mathrm{ml}$ conical flasks containing $50 \mathrm{ml}$ of medium. The flasks were maintained on gyratory shaker at $100 \mathrm{rpm}$. Cultures were incubated at $25 \pm 1^{\circ} \mathrm{C}$ at $16 \mathrm{~h}$ photoperiod and 3000 lux intensity.

\section{Preparation of samples for scanning electron microscopy}

Embryos at various stages of development were fixed for $2 \mathrm{~h}$ at room temperature in $2 \%$ glutaraldehyde buf- ferred to $\mathrm{pH} 7.2$ with cacodylate and post-fixed in $1 \%$ osmium tetroxide overnight. After dehydration through a graded series of ethanol to absolute ethanol, embryos were critical point dried and sputter coated with gold. Observations and photographs were made on Jeol scanning electron microscope at $20 \mathrm{kV}$.

\section{Data collection and analysis}

All the experiments described below were repeated 4 times. Each replicate consisted of 40-50 explants unless otherwise mentioned. All the treatments were arranged in a completely randomized design. Relating to each genotype data on explants forming embryos and mean number of embryos/embryo forming explants (EFEX) were recorded after $35 \mathrm{~d}$ of culture. For plant regeneration all the somatic embryos formed on single leaf explant were transferred to basal MS medium without hormones. Number of plants regenerated/ EFEX was recorded after $30 \mathrm{~d}$ of culture. For the experiment on embryogenic competence in long-term culture, embryogenic stock callus was maintained by subculture on basal MS medium with $0.1 \mathrm{mg} / \mathrm{l}$ NAA and without NAA at 30-d interval. Mean separation was performed by LSD after Fisher's $F$ test. Callusing from the cut end of the leaf explants was noticed after 8-10 d of culture.

\section{RESULTS}

\section{Somatic embryogeny}

Somatic embryos were visible on the leaf explants after 3 weeks of culture. They appeared as round globular masses, loosely attached without vascular connections to parent tissue. Some of the leaf explants directly formed globular embryos without intervening callus. The developmental stages of somatic embryos included globular, heart and cotyledonal stages (figs 1, 2).

In all the 4 genotypes with increase in NAA concentration significant increase in explants forming embryos was observed up to $8.0 \mathrm{mg} / \mathrm{l}$ (table 1). Optimum NAA concentration for highest embryogenic response was different for different genotypes; $8.0 \mathrm{mg} / \mathrm{l}$ was optimum for highest response in Kalalòng (67.2\%), and Suphal (94.3\%) whereas it was $10.0 \mathrm{mg} / \mathrm{l}$ for DRLS (69.8\%) and PPL (81.5\%). At $12.0 \mathrm{mg} / \mathrm{l} \mathrm{NAA}$ concentration there was a significant decrease in embryo formation in all 4 varieties. Embryogenesis was highest in Suphal, followed by PPL, DRLS and Kalalong in decreasing order. 


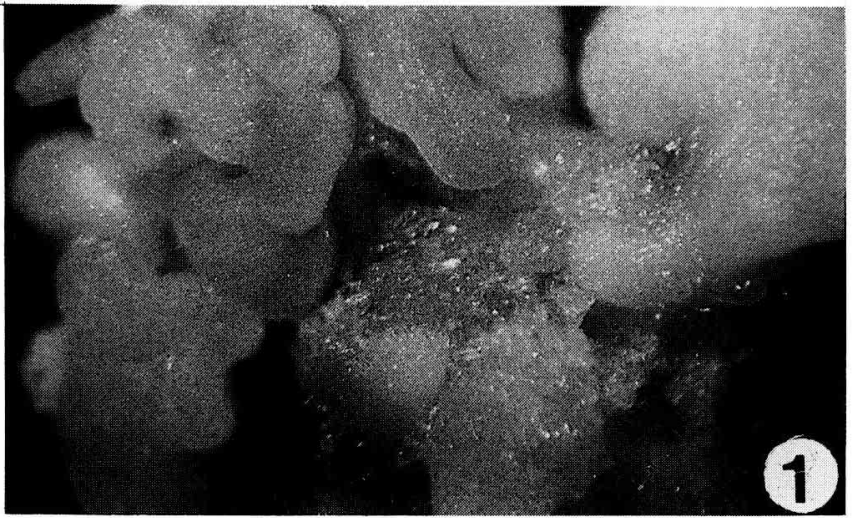

Fig 1. A mass of embryoids from leaf callus $(\times 8)$.

For the experiment on mean number of embryos/EFEX, only those embryos with distinct shoot and root meristems were included for data analysis. The mean number of embryos/EFEX also showed a similar trend of increasing response with increase in NAA concentration. At 0.5 and $4.0 \mathrm{mg} / \mathrm{l}$ NAA concentration, mean number of embryos formed were not significantly different in all 4 varieties. Lowest and highest mean number of embryos/EFEX varied from 3.5 in

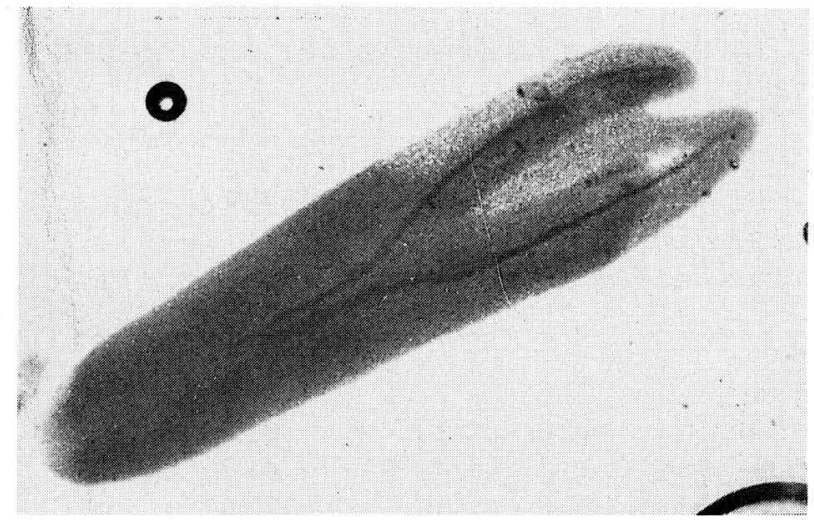

Fig 2. Mature somatic embryo with distinct cotyledons $(x 70)$.

DRLS to 35.0 in Suphal respectively. Stages of embryoid development which were evident in scanning electron micrographs (figs 3,4 ) included globular, heart-shaped somatic embryos with distinct shoot development. Occasionally secondary somatic embryogenesis was also observed in which adventive embryos were formed on somatic embryos. Continued growth of these on parent somatic embryos resulted in abnormal embryo formation.

Table I. Effect of NAA concentration on somatic embryogenesis in four high yielding genotypes of Solanum melongena.

\begin{tabular}{|c|c|c|c|c|c|c|c|}
\hline \multirow[b]{2}{*}{ Genotypes } & \multirow[b]{2}{*}{0.5} & \multirow[b]{2}{*}{1.0} & \multicolumn{3}{|c|}{$N A A$ concentrations (mg/l) } & \multirow[b]{2}{*}{10.0} & \multirow[b]{2}{*}{12.0} \\
\hline & & & 2.0 & 4.0 & 8.0 & & \\
\hline \multicolumn{8}{|c|}{ Explant forming embryos (\%) } \\
\hline DRLS & 15.2 & 18.5 & 21.0 & 54.0 & 66.3 & 69.8 & 52.5 \\
\hline Kalalong & 22.3 & 25.0 & 33.5 & 54.0 & 67.2 & 61.7 & 54.0 \\
\hline Suphal & 28.8 & 35.5 & 55.5 & 73.3 & 94.3 & 85.2 & 68.8 \\
\hline PPL & 16.0 & 30.8 & 45.5 & 58.7 & 74.0 & 81.5 & 66.7 \\
\hline $\operatorname{LSD}(5 \%)$ & 4.82 & 6.19 & 6.57 & 8.12 & 7.44 & 7.28 & 8.49 \\
\hline \multicolumn{8}{|c|}{ Mean number of embryos / EFEX } \\
\hline DRLS & $3.5^{\mathrm{ns}}$ & 5.3 & 6.3 & $14.5^{\text {ns }}$ & 14.0 & 18.5 & 18.5 \\
\hline Kalalong & $4.3^{\text {ns }}$ & 5.8 & 9.0 & $17.0^{\text {ns }}$ & 15.5 & 13.5 & 12.0 \\
\hline Suphal & $7.2^{\text {ns }}$ & 8.7 & 12.3 & $17.7^{\text {ns }}$ & 35.0 & 23.0 & 18.3 \\
\hline PPL & $4.5^{\mathrm{ns}}$ & 8.5 & 10.3 & $16.0^{\text {ns }}$ & 21.0 & 21.7 & 15.8 \\
\hline LSD $(5 \%)$ & 2.93 & 2.44 & 1.77 & 3.97 & 5.23 & 3.28 & 3.83 \\
\hline \multicolumn{8}{|c|}{ Number of plants regenerated / EFEX } \\
\hline DRLS & 1.5 & 3.0 & 4.0 & $11.5^{\mathrm{ns}}$ & 11.0 & 15.0 & 14.3 \\
\hline Kalalong & 2.3 & 3.3 & 6.0 & $14.0^{\text {ns }}$ & 12.8 & 10.0 & 7.5 \\
\hline Suphal & 4.8 & 6.5 & 9.3 & 14.0ns & 29.5 & 17.8 & 13.3 \\
\hline PPL & 2.0 & 5.8 & 7.3 & $12.8^{\text {ns }}$ & 17.8 & 17.3 & 11.7 \\
\hline $\operatorname{LSD}(5 \%)$ & 2.14 & 2.57 & 1.86 & 3.43 & 4.41 & 3.47 & 3.57 \\
\hline
\end{tabular}

All media were supplemented with $0.1 \mathrm{mg} / \mathrm{l}$ kinetin. Values are means of 4 replicates. Mean separation was performed separately for each group. ns: non-significant. 
Table II. Effect of initial inoculum size on plant regeneration.

\begin{tabular}{lllll}
\multirow{2}{*}{$\begin{array}{l}\text { Initial } \\
\text { embryogenic } \\
\text { callus (mg FN) }\end{array}$} & DRLS & Kalalong & Suphal & PPL \\
\hline & & & & \\
\hline 75 & 34.6 & 27.0 & 50.0 & 40.0 \\
150 & 46.0 & 30.0 & 60.0 & 56.0 \\
300 & 33.3 & 42.6 & 41.7 & 36.0 \\
600 & 20.8 & 19.1 & 23.3 & 21.6 \\
900 & 16.7 & 15.5 & 17.7 & 16.1
\end{tabular}

Values are means of 20 flasks. FW: fresh weight, E: embryogenic callus.

The entire leaf sections with embryogenic callus and embryos were carefully removed and individually transferred to basal MS medium without hormones for plant regeneration (fig 5). Those embryoids formed directly on the edges of the leaves could be removed and plated singly on basal medium. Some of the transferred embryos developed only shoots or roots. Only those embryos which formed complete plants were included for data analysis. Somatic embryos which were initiated on media with low NAA concentration, ie $0.5-2.0 \mathrm{mg} / \mathrm{l}$, showed faster plant regeneration and a better developed root system than those formed on high NAA concentration. The highest number of plants regenerated/EFEX in DRLS, Kalalong, Suphal and PPL were 15.0, $14.0,29.5$ and 17.8 respectively. Plants with a well developed root system (fig 6) were hardened under high humidity conditions before transfer to the field (fig 7) and were successfully grown to maturity (fig 8).

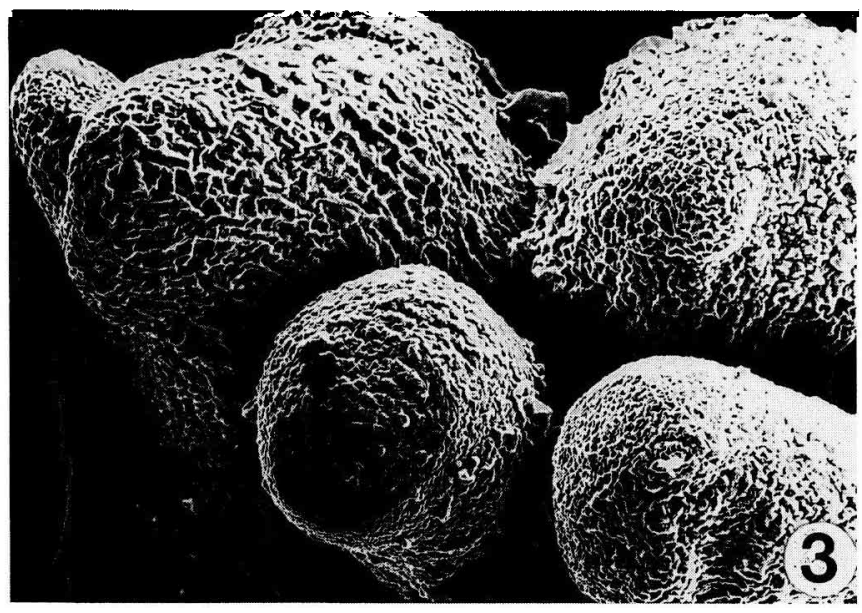

Fig 3. Scanning electron micrograph of globular embryos (x110).

\section{Effect of initial inoculum size on plant regeneration}

Embryogenic calli of 75-900 $\mathrm{mg}$ fresh weight (fw) were inoculated on basal MS medium without hormones. Number of plants regenerated was recorded after 4 weeks of culture (table II). The maximum number of plants regenerated per $\mathrm{g}$ fw of embryogenic callus was produced when inoculum size was $150 \mathrm{mg} f w$ in varieties DRLS, Suphal and PPL. However, it was $300 \mathrm{mg}$ in the case of Kalalong. Any increase in inoculum size beyong the optimum $f w$ in individual genotypes decreased the frequency of plant regeneration.

\section{Effect of long-term culture on embryogenic competence}

Random pieces of embryogenic calli (300-320 $\mathrm{mg}$ ) from stock callus were transferred to basal medium with and without $0.1 \mathrm{mg} / \mathrm{INAA}$. On media supplemented with $0.1 \mathrm{mg} / \mathrm{l} \mathrm{NAA}$, the embryogenic competence in terms of percent callus explants forming somatic embryos and number of plants regenerated were significantly reduced by the 4 th passage. Fifty and $75 \%$ decline (in percent explants forming somatic embryos) were noticed by 8 th and 12th passage respectively. Number of plants regenerated/callus explant showed a 7-fold decrease from the 2nd to 12th passage in all 4 genotypes. On NAA free media $50 \%$ decline was observed in the 4th passage in percent callus explants forming somatic embryos. The number of plants regenerated/callus explant did not differ significantly on media with and without NAA in contrast to percent explants forming somatic embryos. Plants regenerated after prolonged culture were found to be phenotypically normal and were successfully established on soil.

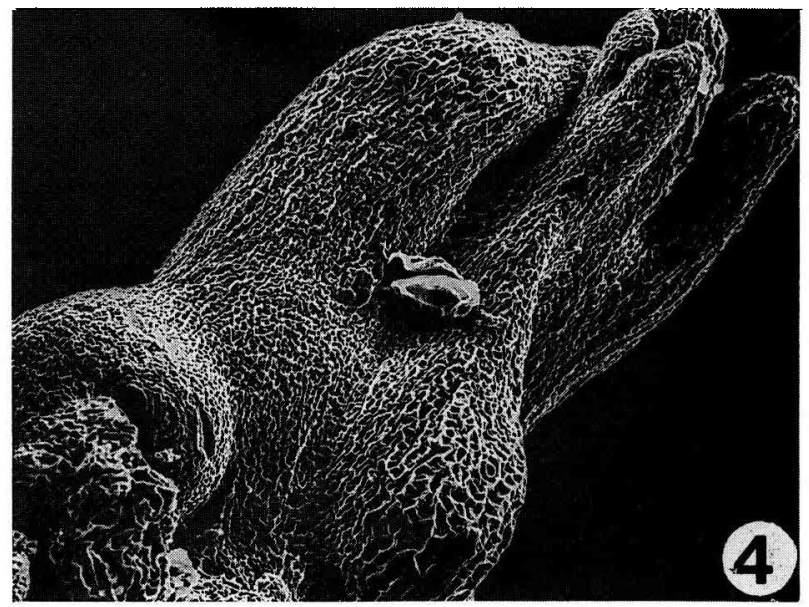

Fig 4. Scanning electron micrograph of shoot development from somatic embryo $(\times 110)$. 


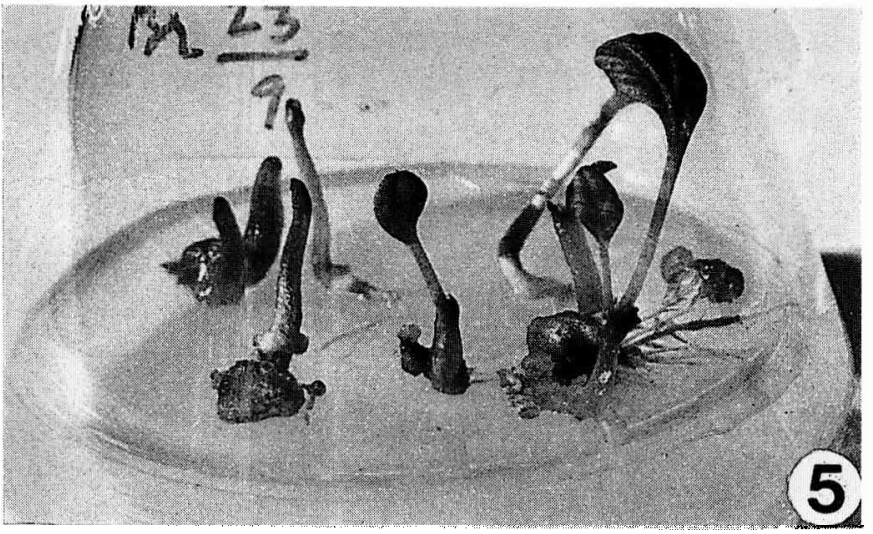

Fig 5. Early stages of plant regeneration from somatic embryos on basal medium.

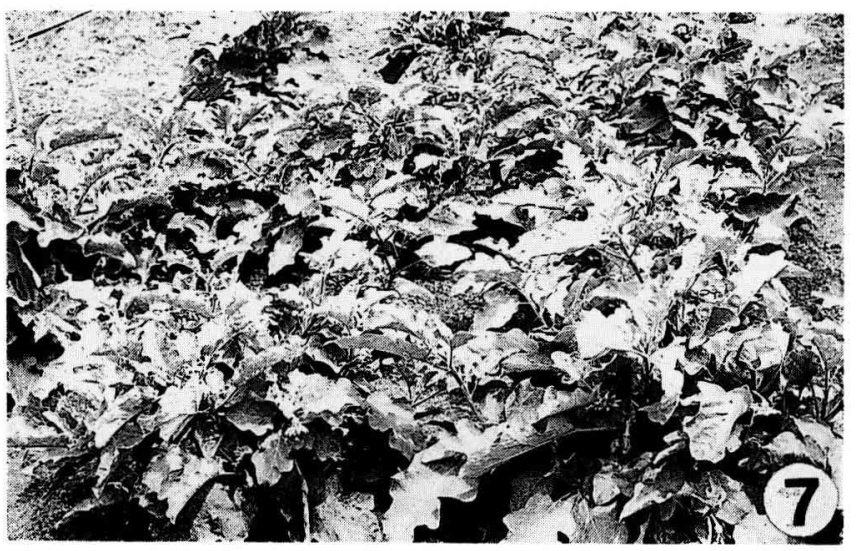

Fig 7. Field-transferred in vitro plants.

\section{DISCUSSION}

The present study has shown the induction of a high frequency of somatic embryogenesis from leaf explants of 4 high yielding varieties of $S$ melongena $\mathrm{L}$. The frequency of somatic embryogenesis achieved was higher than that reported earlier for this species (Kamat and Rao, 1978; Matsuoka and Hinata, 1979). Gleddie et al (1983) obtained somatic embryogenesis in this species on media containing NAA only. But in the present study, the frequency of somatic embryo formation and plant regeneration were higher when the medium was supplemented with $0.1 \mathrm{mg} / \mathrm{l}$ kinetin in addition to NAA. Distinct genotypic response was noticed in respect of optimum NAA concentration, intensity of somatic embryo formation, and plant regeneration. Similar genotypic differences were noticed regarding embryogenic competence in long-term culture and initial inoculum size in plant regeneration.

The cellular origin of embryogenic callus or embryoids was not studied. However, in those cases where somatic embryos were formed from

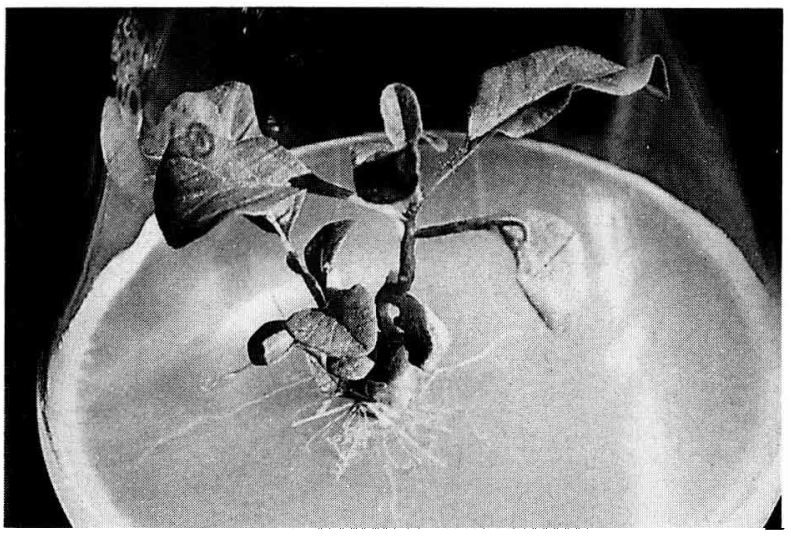

Fig 6. Complete plant with well developed root system.

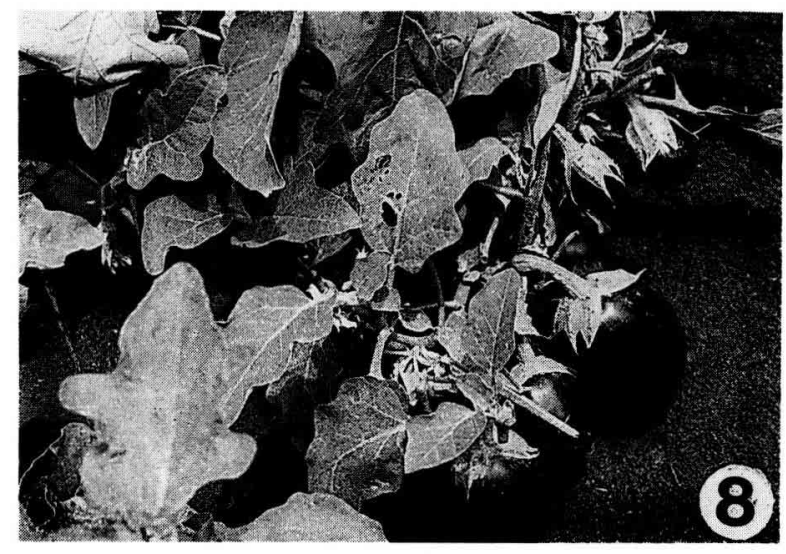

Fig 8. Plants in bearing stage.

callus, the origin may be from differentiated cells which have dedifferentiated and subsequently been redetermined for embryogenic development. This process has been reported in a number of species and this also holds true for androgenesis (Raghavan, 1976; Tisserat et al, 1979; Williams and Maheswaran, 1986). Results of the present study on the effect of initial inoculum size on callus growth and plant regeneration are in agreement with similar studies in several species (Caplin, 1963; Bhattacharya et al, 1981). In the present study, when inoculum was either smaller or larger than the optimal callus size, plant regeneration was reduced. Based on their study in Pokkali rice, Raghava Ram and Nabors (1985) have suggested that callus may release some factor into the medium which influences plant regeneration. This conditioning factor could not be produced in sufficient amounts when a smaller than optimal callus was used. A larger callus could deplete the medium of this factor or required nutrient.

In the present study though there was a decline in embryogenic competence with increase 
Table III. Effect of long-term culture on embryogenic competence and plant regeneration in four genotypes of Solanum melongena $L$, on media containing $0.1 \mathrm{mg} / /$ NAA $(A)$ and without NAA (B). 40 calluses were transferred in each case.

Genotypes
and medium

\section{and medium}

ages

2

4

6

8

10

12

DRLS
A

B

$65.0^{*}$
$14.0^{* *}$

B 58.0

10.0

Kalalong

Suphal

PPL

58.0
11.0
46.2
6.0

40.0
7.3
28.4
4.0

30.2
4.0
15.0
3.0

$\begin{array}{rc}20.0 & 15.0 \\ 3.1 & 1.8 \\ 9.2 & 6.0 \\ 3.0 & 1.2\end{array}$

A

B
A

B

$B$

62.0

12.0

51.0

9.0

A

B
$90.0 \quad 75.0$

$27.0 \quad 20.0$

80.0

22.4

63.0

14.0

54.0
8.1
45.2
6.2

6.2

35.0
6.8
25.0
4.5

28.0
3.5
13.6
3.0

\section{5}

12.4

39.2

8.2

$\begin{array}{rr}78.0 & 62.0 \\ 15.7 & 12.6 \\ 68.5 & 50.0 \\ 11.0 & 8.0\end{array}$

47.3
7.8
33.5
5.0

$\begin{array}{rrr}44.2 & 35.4 & 22.0 \\ 8.1 & 5.4 & 3.6 \\ 23.0 & 16.8 & 10.0 \\ 5.0 & 4.0 & 3.0\end{array}$

$\begin{array}{rr}21.0 & 14.2 \\ 2.3 & 2.0 \\ 9.0 & 5.0 \\ 2.0 & 2.0\end{array}$




\section{REFERENCES}

Bhattacharya S, Chatterjee S, Biswas P, Mukherjee B (1981) Role of inoculum weight on physiology of growth and development of Corchorus oletorius and Nigella sativa tissues cultured in vitro. Indian $J$ Exp Bot 19, 1030-1032

Caplin SM (1963) Effect of initial size on plant tissue cultures. Am J Bot 50, 91-94

D'Amato $F$ (1978) Chromosome number variation in cultured cells and regenerated plants. In: Frontiers of Plant Tissue Culture (Thorpe TA, ed) Univ Calgary Press, 287-295

Gleddie S, Keller W, Setterfield G (1983) Somatic embryogenesis and plant regeneration from leaf explants and cell suspensions of Solanum melongena $L$ (egg plant). Can J Bot 61, 656-666

Kamat MG, Rao PS (1978) Vegetative multiplication of egg plants (Solanum melongena) using tissue culture techniques. Plant Sci Lett 13, 57-65

Matsuoka H, Hinata K (1979) NAA induced organogenesis and embryogenesis in hypocotyl callus of Solanum melongena L. J Exp Bot 30, 363-370

Murashige T, Skoog $F$ (1962) A revised medium for rapid growth and bioassays with tobacco. Physiol Plant 15, 473-497

Padmanabhan V, Paddock EF, Sharp WK (1974) Plantlet formation from Lycopersicon esculentum leaf callus. Can J Bot 52, 1429-1432
Raghavan V (1976) Experimental Embryogenesis in Vascular Plants. Academic Press, New York, 349381

Raghava Ram NV, Nabors MW (1985) Plant regeneration from tissue cultures of Pokkali rice is prompted by optimising callus to medium volume ratio and by a medium conditioning factor produced by embryogenic callus. Plant Cell Tissue Organ Cult 4, 241-248

Rao Lakshmana PV, Singh B (1991) Plantlet regeneration from encapsulated somatic embryos of hybrid Solanum melongena L. Plant Cell Rep 10, 7-11

Smith EM, Street HE (1974) The decline in embryogenic potential as callus and suspension cultures of carrot (Daucus carrota) are serially subcultured. Ann Bot 38, 223-241

Stuart DA, Strickland SG, Walker KA (1987) Bioreactor production of alfalfa somatic embryos. Hortscience 22, 800-803

Tisserat B, Esan EB, Murashige T (1979) Somatic embryogenesis in angiosperms. Hortic Rev 1, 1-78

Williams EG, Maheswaran G (1986) Somatic embryogenesis: factors influencing coordinated behaviour of cells as an embryogenic group. Ann Bot 57, 443462

Yamada T, Nakagawa H, Sinoto $Y$ (1967) Studies on the differenciation of cultured cells. I. Embryogenesis in three strains of Solanum callus. Bot Mag, Tokyo $80,68-7$ 